\title{
Strategies and Mechanisms That Would Be Adopted To Enhance Food Production in Kenya.
}

\author{
Dr, Chukwu Rosebella Cheptoo \\ Department of Hospitality Tourism and Consumer Science, Eldoret Polytechnic-KENYA
}

\begin{abstract}
According to International Fund for Agriculture Development, poverty in Africa emanates from low farm incomes and unemployment. In Kenya, this is not different because about $80 \%$ of the farmers are of smallscale owing less than two ha of land and depend mainly on agriculture as their source of livelihood. This paper established the strategies and mechanisms that would be adopted to enhance food production in Kenya. Summative Evaluation research design was adopted and 400 rural households formed the target population. Multi-stage random sampling was used to select a sample of 60 respondents. Questionnaires, interview schedules and focus group discussion guide were used to collect data, which was thereafter analyzed using descriptive statistics and nomothetic evaluation. The study found out that strategies on improving food production include and not limited to: investment in agricultural sector than other sector, building on indigenous knowledge of agricultural management, incorporating new technology, developing and supporting serious mitigation and adaptation policies on climate change. It was concluded that developing economic policies and intervention strategies that are pro-poor and pro-famers would improve food production. It was further recommended that there is need for the government to streamline the land tenure inequalities and develop multiple guidelines that enhance access to land ownership by the poor and women.
\end{abstract}

Keyword: Strategies, Mechanisms, Food Production

\section{Introduction}

Achieving food security in its totality continues to be a challenge not only for the developing countries but also for the developed nations. The difference lies in the magnitude of the problem in terms of its severity and proportion of the population affected. In developed nations the problem is alleviated by providing targeted food security strategies including food aid in the form of direct food relief, food stamps or indirectly through subsidized food production, (Mwaniki, A. 2007). In Kenya over 75\% of its population earn its living from agriculture, which in turn depends on rainfall and according to the FAO, three quarters of the poor on the Planet currently live in rural areas and agriculture constitutes a means of subsistence for $86 \%$ of rural population. The agriculture and food security sectors and in particular women who constitute a large proportion of the agriculture labor force and produce 60 to $80 \%$ of food in the majority of developing countries, play an essential role in the struggle for food security. While large commercial agricultural activities are often dominated by men. The control of women over the means of agricultural production and in particular land ownership is becoming weaker with the globalization and commercialization of food industry. In 2010, the number of malnourished people was close to one billion and the call for an international response that is coordinated and tailored to the complexity of the challenge is becoming all the more insistent (ROK, 2003).

Over the years, the Government and Non-Governmental Organizations have focused resources and expertise on particular areas rather than integrating interrelated concerns into a holistic approach to food insecurity. Moreover it is been believed that specialization and commercialization in agriculture is part of a border strategy of improving farm income. The argument behind this is that farmers are constrained in terms of resources and hence cannot produce multiple crops at the same time (IAC, 2006). On the other hand, agricultural diversification and trade-off arising from the notion that benefits from different agricultural enterprises do not fall simultaneously, so that, in case income from one enterprise falls, it will be compensated by the rising income of the other enterprise(s). It is therefore a risk management strategy which farmers employ to increase and stabilize farm income. In addition diversification provides an opportunity to exploit potential complementary relationship between enterprises though improved utilization of the scarce resources (Thaxron, 2008).

\section{Food Security In Kenya}

Agriculture has been the mainstay of the Kenyan economy but its contribution to the GDP has been declining (GOK, 2010). It is the basis for food security, economic growth, employment creation and foreign exchange creation. Most Kenyan industrial and manufacturing firms are agro-based. The development strategy depends on agriculture and industry for faster economic growth (MOP, 2009). Kenya was plunged into a state of emergency in 2009 as one of the world's most serious hunger zones. The failure of seasonal rains in successive 
years in some regions forced 3.8 million people into dependency on international food aid (FEWS NET, 2010). Whilst the exceptional weather pattern was its immediate cause, the food security crisis was the culmination of many years of the mismanagement of the agriculture sector and its associated climate risk. The United Nations' Development Assistance Framework for Kenya for the period 2009-2013 notes that the nutrition situation of the country's children has not improved in the past 20 years. Rural economic policies have been fragmented across government departments, leaving small farmers with limited access to credit, technical advice and direct financial support. Land rights have been unsettled by overt political gerrymandering and the disaster management policy floundered with the national grain reserve depleted by corrupt officials. This affirms that the goal of food security in Kenya has formidable obstacles to overcome

\section{Food Security Intervention Strategies}

There are several different dimensions of food production systems that need to be taken into account with regards to food security. For example, it is unlikely that technology alone can provide the solution for the food security challenge enhance, adapting to the additional threats to food insecurity arising from major environmental changes requires an integrated food system approach, not just a focus on agricultural practices. Adapting food systems to global environmental change requires more than just technological solutions to increase agricultural yields, trade-offs across multiple scales among food system outcomes are a pervasive feature of security. Nevertheless more attention needs to be paid to the governance of food systems (ESP, 2009).

\section{Research Methodology}

This study adopted a summative evaluation research design. A summative evaluation research design is used to provide the public and decision markers with information to determine a program's worth or merits. The target population was 400 rural households. Multi-stage random sampling was used to get a sample size of 60 respondents. Structured questionnaires, interview schedules and focus group discussion guides were used to collect data. To analyses data, the study adopted descriptive statistics and nomothetic methods.

\section{Results And Discussions}

The study established that, the United Nations' Development Programmer's Regional Bureau for Arab States (2009) gives the following guidelines as strategies towards achieving food security in rural households: Develop multi-sartorial policies to address: a Gender roles, by making sure women, who make up an ever increasing share of agricultural producers, are provided with access to land, appropriate tools, extension services, and secure access to productive land and credit; also develop water policies to invest heavily in improving water availability, yield and distribution, and prioritize water use, increase investment in dripirrigation, develop equitable access to water resources in rural and urban areas, renew support for traditional water control systems and for indigenous research and development, support less water-intensive crops, build on indigenous knowledge of agricultural management and incorporate newer technology when necessary (UNDP, 2009)

The third strategy is to develop economic policy interventions to be pro-poor and pro-farmer, specifically to empower redistributive public support, in the form of financial transfers, to facilitate a pro-poor pattern of public goods provision, increase investment of smallholder agricultural sections, and increase credit available through rural financial systems, expand non-farm and farm-labor intensive activities within rural areas. Resolving land tenure inequalities by imposing progressive land taxation, increasing the rights of peasant households by allowing peasants greater control over land, ensuring that property rights systems are bias against women would be a good strategy. Increase smallholders' access to essential production inputs. and regular surveys of income and expenditure, agricultural census covering both cropping and livestock and labor force survey so that policies can be based on regular and timely data sets, develop better extension services for poorer landholding households, commercial banks to diversify their lending and extend their operations to rural areas (Wolgin, 2001).

The fourth strategy is to develop and support serious mitigation and adaptation policies on climate change, Increase awareness on causes and potential impacts of climate change and mitigation and adaptation methods, work nationally, regionally and internationally to curb the greenhouse gas emission positive trends, enhance disaster preparedness and develop regional and local early warning systems to monitor disasters such as high intensity storms and sea-water rise.

Other strategies suggest that the food-deficit developing countries should maximize the efficiency and output of their export sectors and then use the resulting foreign exchange earnings to import food. According to this strategy, continued growth in world trade will allow them to produce and export other primary products, industrial goods and services that should enable them to purchase significant quantities of food from foodsurplus countries in both the North and the South. For this food to reach the food-insecure in poor countries, the 
development of effective national food security policies is required (Saad, 1999). The FAO (2005) suggests that these policies must ensure higher food entitlements for both the rural and urban poor through sufficient access to food made possible by income generation and employment.

Another strategy, thought to be more realistic by many analysts, suggests that food deficit countries in the South should re-orient their development strategies toward increased investment in their agricultural sectors. They need to increase their own food production significantly and adopt specific policies to alleviate food insecurity at national, regional and household levels (Saad, 1999). According to projections by (Rungeal,et.2003), the good news is that with significant increases in agricultural productivity and economic growth, reduction in population growth rare, and increased investments in education and health, the number of under-weight children in Sub-Saharan Africa could be reduced by more than one third to 22 million by 2025. To achieve this, crop yield would have to increase by 3 percent annually, and total GDP by $8-10 \%$ each year. The study also established that access to credit facilities, use of hybrid seeds and subsidies on inputs among other factors are the mechanisms that would increases food production.

Table 4.1 Suggestions on improving food production

\begin{tabular}{lll}
\hline Suggestions & Frequency & Percentage \\
\hline Increase size of farms & 62 & 35.4 \\
Give subsidies on fertilizer & 50 & 28.6 \\
Use hybrid seeds & 17 & 9.7 \\
Get enough capital & 13 & 7.4 \\
Create IGAs & 9 & 5.1 \\
Provision of credit facilities & 9 & 5.1 \\
Seeking alternative sources of income & 8 & 4.6 \\
Diversify farming & 4 & 2.3 \\
Avoid selling maize & 1 & 0.6 \\
Grow more maize & 1 & 0.6 \\
Look for a fertile piece of land & 1 & 0.6 \\
\hline Total & $\mathbf{1 7 5}$ & $\mathbf{1 0 0 . 0}$ \\
\hline Source: Research 2013 & & \\
\hline
\end{tabular}

A Chi Square test conducted on the responses showed that there was a highly significant $(\mathrm{p}<0.01)$ variation $\left(\chi_{10,0.01}^{2}=152.96\right)$. From the results suggestions on improving households' food security were as follows: increasing the farm sizes, giving farmers' subsidies on fertilizer, use of hybrid seeds and getting enough capital were very significant factors that would help enhance agricultural production. This in-turn translates to enhanced household food security by increasing availability and access to the food produced. Employment in off-farm and non-farm activities has a paramount significance to diversify the sources of farm households' livelihoods. It enables farmers to modernize their production by giving them an opportunity for applying the necessary inputs and reduce the risks of food shortages during period of unexpected crop failures (Haile et.al 2005).

From FGDs, Strategies on improving on food production ranked in their order of importance include; increasing investment in agricultural sectors than other sectors, building on indigenous knowledge of agricultural management and incorporate new technology, developing and supporting serious mitigation and adaptation policies on climate change, reducing input prices and opening export markets to the rural households, developing economic policies to be pro-poor and pro-farmer, developing better extension services for poorer landholding households, resolving land tenure inequalities and development of multiple guidelines that enhance access to land ownership by the poor and women.

The study revealed that improvement of infrastructure would improve the availability, accessibility and affordability of food

Table 4.2: Suggestions on improving the availability, accessibility and affordability of food

\begin{tabular}{lll}
\hline solution & Frequency & Percent \\
\hline Tarmac the roads & 111 & 70.3 \\
Murrum the roads & 47 & 29.7 \\
\hline & $\mathbf{1 5 8}$ & $\mathbf{1 0 0 . 0}$ \\
\hline
\end{tabular}

A Chi Square test conducted on the responses showed that there was a highly significant $(\mathrm{p}<0.01)$ variation $\left(\chi_{1,0.01}^{2}=16.41\right)$. Majority of respondents $(70.3 \%)$ recommended that the roads need to be tarmacked while $29.7 \%$ indicated that the roads need to be murrumed. Farmers were of the view that a good 
road network would facilitate easy and cheap transport of farm inputs as well as transportation of farm produce to the market. FGDs indicated that much time is wasted in transportation during rainy seasons because of the impassable roads. The means of transport available during the rainy seasons are mainly tractors which are not only uncomfortable slow but also risky.

The study further found out that coping mechanism like skipping meals, eating less preferred food and borrowing from friends and relatives would be employed against food insecurity.

Table 4.3: Coping mechanism against food insecurity.

\begin{tabular}{lll}
\hline Coping mechanism & Frequency & Percentage \\
\hline Buying food & 43 & 10.8 \\
Skipping meals & 29 & 7.3 \\
Burning Charcoal & 22 & 5.5 \\
Selling cows & 17 & 4.3 \\
Alternative sources of income & 12 & 3.0 \\
Business & 1 & 0.3 \\
Leasing land & 1 & 0.3 \\
Sell milk & 1 & 0.3 \\
Sell poultry & 1 & 0.3 \\
\hline Total & $\mathbf{1 2 7}$ & $\mathbf{9 3 . 5}$ \\
\hline
\end{tabular}

Source: Researcher 2013

A Chi Square test carried out showed that there was a highly significant $(\mathrm{p}<0.01)$ variation ( $\left.\chi_{9,0.01}^{2}=83.13\right)$ in the responses. From the results, the coping mechanisms employed against food insecurity were buying food (10.8\%), skipping meals $(7.3 \%)$, burning charcoal $(5.5 \%)$, selling cows $(4.3 \%)$, and alternative sources of income (3.0\%), business $(0.3 \%)$, leasing land $(0.3 \%)$, selling milk $(0.3 \%)$ and selling poultry $(0.3 \%)$. Farm households respond to the problems caused by seasonal and disasters related to food insecurity in different ways. The range of coping and adaptive strategies is large and differs according to the particular conditions. From key informant interviews, coping mechanisms employed by residents of UasinGishu County in mitigating food security include; reduction in food wastage, stocking of maize in times of surplus, renting of land for agricultural production, engaging in alternative sources of livelihoods to reduce dependency on agriculture, family planning to reduce over dependency, using certified seeds, investing in dairy farming to reduce dependency on crop farming, borrowing food from friend and relatives, buying food, selling of household goods to buy food, planting in swampy places during dry season, crop diversification and eating less preferred foods. From FGDs, coping mechanisms/strategies employed by households to mitigate food insecurity include; buying and stocking maize when the prices are low, exploring alternative sources of income, engaging in dairy farming to supplement crop farming and not selling harvested maize.

\section{Conclusion And Recommendation}

It was concluded that increasing investment in agricultural sector, building on indigenous knowledge of agriculture management, supporting serious mitigation and adaptation polices on climate change and incorporation of new technology in agriculture would improve food production. It was recommended that there is need for the government to streamline land tenure inequalities and develop multiple guidelines that enhance access to land ownership by the poor and women.

\section{References}

[1]. CAADP, (2010). How are countries increasing up to the Maputo declaration? Policy Brief, Comprehensive Africa Agriculture Development Programme. Retrieved from: www.repad-caadp.net/pdf/How\%20are\%20countries\%20measuring \%20up\%20to\%20the\%20Maputo\%20 declaration.pdf. On 17 June 2012.

[2]. Evans, A. (2009). The Feeding of the Nine Billion: Global Food Security for the $21^{\text {st }}$ Century. AChatham House Report. London : The Royal Institute for International Affairs.

[3]. FAO, (2009). "Measures of enhance Global Food Security: Rural Development Smallholder Farmer and Trade Consideration". Rome, Italy.

[4]. FAO, (2008). Climate Change and Food Security: A Framework Document. FAO.Rome.

[5]. FAO,(2006). The State of the World Fisheries and Aquaculture. FAO.Rome,Italy

[6]. FAO.(2006a)'.World Agriculture: towards 2030/2050','FAO Global Study, June.

[7]. FAO, (2002). The State of Food Insecurity in The World. Retrieved from: www.fao.org/../y7352e00.htm Accessed on 6th April 2012.

[8]. FAO, (2000). The State of World Fisheries and Aquaculture. Retrieved from: www.fao.org/../x8002e00.htm Accessed on 12th April 2012.

[9]. GOK, (2004). Strategy for Revitalizing Agriculture 2004-2014: Prepared by: Ministry of Agriculture and Ministry of Livestock and Fisheries Development. 
[10]. GOK, (2010).Food Production based on Cereal Production in the Districts for the year 2010. Statistics obtained from Ministry of Agriculture.

[11]. Haile, H.K, Alemu, Z.G and KUDH land G. (2005),cause of household food insecurity in Kcoredagaga peas and Association, Dromilya zone, Ethiopia, University of Free state.

[12]. IAC,Report (2004). Food Security in Africa. Retrieved from: www.interacademycouncil.net/File.aspx Accessed on 11th Jan 2012

[13]. IAC, Report (2004b). Realizing the Promise and Potential of African Agriculture. Retrieved from: www.interacademycouncil.net/240026/AfricanAgriculture.aspx Accessed on 11th Jan 2012.

[14]. IFAD, (2001). Rural Poverty Report. Retrieved from www.ifad.org/pub/ar/2001/e/index.htm Accessed on 11th Jan 2012.

[15]. Mwaniki,A. (2007). Achieving Food Security in Africa: Challenges and Issues.

[16]. Republic of Kenya. (2004).Strategy for Revitalizing Agriculture (2004-2014).Ministry of Agriculture and Ministry of Livestock and Fisheries Development. Nairobi, Kenya.

[17]. Republic of Kenya . (2004). Economic Survey, Central Bureau of Statistics. Ministry of Planning and National Development, Government Printers, Nairobi, Kenya.

[18]. Republic of Kenya. (2004). Statistical Abstract, Central Bureau of Statistics. Ministry of Planning and National Development, Government Printers, Nairobi, Kenya.

[19]. Republic of Kenya. (2003).Economic Survey, Central Bureau of Statistics. Ministry of Planning and National Development, Government Printers, Nairobi, Kenya.

[20]. Republic of Kenya. (2003). Statistical Abstract, Central Bureau of Statistics. Ministry of Planning and National Development, Government Printers, Nairobi, Kenya.

[21]. Republic of Kenya ROK. (2004) “The Short Rain Season Assessment Report.” Kenya Food Security Steering Group (KFSSG) 2010.

[22]. Saad, M.B. (1999). Food Security for the Food-Insecure: New Challenges And Renewed Commitments. Centre for Development Studies, University College Dublin, Ireland.

[23]. Seid, F.H. (2007). Food Insecurity and Its Determinants In Rural Households In Amhara Region. Addis Ababa University, Ethiopia.

[24]. Thaxtron, M. (2008).Integrating Population. Health Environment in Kenya. Retrieved form; www.prd.org/kenya Accessed on 24th Aug 2012.

[25]. United Nations Development Programme Regional Bureau for Arab States (2009). Development Challenges for the Arab Region: Food Security and Agriculture Volume 2.

[26]. United Nations Development Programme Regional Bureau for Arab States (2009). Development Challenges for the Arab Region: Food Security and Agriculture Volume 2.

[27]. World Bank, (2008). World Development Report 2008: Agriculture for Development. Washington, DC. Available at: http://econ.worldbank.org/WBSITE/EXTERNAL/EXTDEC/EXTRESEARCH/EXTWDRS/EXTWDR2008/0,menuPK:2795178 p agePK:64167702 piPK:64167676 theSitePK: 2795143,00.html.

[28]. World Food Program, (WFP) (2005). CHS Regional Analysis: Household Vulnerability and the Impact of Food Aid: Prepared by TANGO International, Inc. (Technical Assistance for Non Government Organization)

[29]. WHO (World Health Organization), 1997. Third Report on the World Nutrition Situation. Administrative Committee on Nutrition/Subcommittee on Nutrition (ACC/SCN) Geneva.

[30]. WHO.(2009). Strategies for reduction of child mortality. $2^{\text {nd }}$ Report on moving towards MDG. 